\title{
Leveraging PET to image folate receptor a therapy of an antibody-drug conjugate
}

\author{
Christian Brand ${ }^{1}$, Ahmad Sadique 1 , Jacob L. Houghton ${ }^{1}$, Kishore Gangangari ${ }^{1,2}$, Jose F. Ponte ${ }^{3}$, Jason S. Lewis ${ }^{1,4,5}$, \\ Naga Vara Kishore Pillarsetty, ${ }^{1,5}$ Jason A. Konner ${ }^{5,6}$ and Thomas Reiner ${ }^{1,5^{*}}$
}

\begin{abstract}
Background: The folate receptor a (FRa)-targeting antibody-drug conjugate (ADC), IMGN853, shows great antitumor activity against FRa-expressing tumors in vivo, but patient selection and consequently therapy outcome are based on immunohistochemistry. The aim of this study is to develop an antibody-derived immuno-PET imaging agent strategy for targeting FRa in ovarian cancer as a predictor of treatment success.

Methods: We developed [ ${ }^{89} \mathrm{Zr}$ ZZr-DFO-M9346A, a humanized antibody-based radiotracer targeting tumorassociated FRa in the preclinical setting. ${ }^{89} \mathrm{Zr}$ ZZr-DFO-M9346A's binding ability was tested in an in vitro uptake assay using cell lines with varying FRa expression levels. The diagnostic potential of $\left.{ }^{89} \mathrm{Zr}\right] \mathrm{Zr}-\mathrm{M} 9346 \mathrm{~A}$ was evaluated in KB and OV90 subcutaneous xenografts. Following intravenous injection of [ ${ }^{89} \mathrm{Zr}$ ZZr-DFO-M9346A ( 90 $\left.\mu \mathrm{Ci}, 50 \mu \mathrm{g}\right)$, PET imaging and biodistribution studies were performed. We determined the blood half-life of [ ${ }^{89} \mathrm{Zr}$ ]Zr-DFO-M9346A and compared it to the therapeutic, radioiodinated ADC [131 I]-IMGN853. Finally, in vivo studies using IMG853 as a therapeutic, paired with ${ }^{89} \mathrm{Zr}$ ZZr-DFO-M9346A as a companion diagnostic were performed using OV90 xenografts.
\end{abstract}

Results: DFO-M9346A was labeled with Zr-89 at $37{ }^{\circ} \mathrm{C}$ within $60 \mathrm{~min}$ and isolated in labeling yields of $85.7 \pm 5.7 \%$, radiochemical purities of $98.0 \pm 0.7 \%$, and specific activities of $3.08 \pm 0.43 \mathrm{mCi} / \mathrm{mg}$. We observed high specificity for binding FRa positive cells in vitro. For PET and biodistribution studies, $\left.{ }^{[99} \mathrm{Zr}\right] \mathrm{Zr}-\mathrm{M} 9346 \mathrm{~A}$ displayed remarkable in vivo performance in terms of excellent tumor uptake for KB and OV xenografts $(45.8 \pm 29.0 \% \mathrm{lA} / \mathrm{g}$ and $26.1 \pm 7.2 \% \mathrm{IA} / \mathrm{g})$, with low non-target tissue uptake in other organs such as kidneys $(4.5 \pm 1.2 \% \mathrm{IA} / \mathrm{g}$ and $4.3 \pm 0.7 \% \mathrm{lA} / \mathrm{g})$. A direct comparison of the blood half life of $\left[{ }^{89} \mathrm{Zr}\right] \mathrm{Zr}-\mathrm{M} 9346 \mathrm{~A}$ and $\left[{ }^{131} \mathrm{I}\right]-\mathrm{IMGN} 853$ corroborated the equivalency of the radiopharmaceutical and the ADC, paving the way for a companion PET imaging study.

Conclusions: We developed a new folate receptor-targeted ${ }^{89} \mathrm{Zr}$-labeled PET imaging agent with excellent pharmacokinetics in vivo. Good tumor uptake in subcutaneous KB and OV90 xenografts were obtained, and ADC therapy studies were performed with the precision predictor.

Keywords: ${ }^{89} \mathrm{Zr}$, Companion diagnostic, PET imaging, Antibody-drug-conjugate

\section{Background}

Over the last years, the development of novel antibodydrug conjugates (ADCs) has been a trending topic in cancer therapy [1]. This technology uses an antibody to deliver a cytotoxic drug selectively to a tumor cell population by targeting tumor-associated receptors. There are several reasons driving the development of antibody-drug conjugates for cancer treatment. One feature is that a

\footnotetext{
* Correspondence: reinert@mskcc.org

${ }^{1}$ Department of Radiology, Memorial Sloan Kettering Cancer Center, 1275 York Avenue, New York, NY 10065, USA

${ }^{5}$ Department of Radiology, Weill Cornell Medical College, New York, NY 620, USA Full list of author information is available at the end of the article
}

humanized or human antibody bears very high specificity and affinity towards its cancer specific antigen [2]. Another feature is that some of the most potent non-targeted chemotherapeutics such as maytansine have extensive side effects in patients [3], which intuitively could be reduced by targeting the drugs to their intended site of action. However, the transition of antibody-drug conjugates into the clinic would benefit greatly from non-invasive precision predictors that could potentially allow for patient stratification and early evaluation of effectiveness. Patient stratification according to the expression of membranebound antigens typically requires invasive biopsy via 
needle aspiration of multiple tissue regions to overcome tumor heterogeneity. In addition, decisions regarding patient management are often made by using archived biopsy results that do not necessarily reflect antigen expression at the time of treatment.

Mirvetuximab soravtansine (IMGN853) is an antibody -drug immunoconjugate that consists of a humanized monoclonal antibody (M9346A) targeting folate receptor alpha (FR $\alpha)$-positive cancer cells [4] attached to a highly potent cytotoxic maytansinoid, DM4 (Fig. 1) [5]. Although IMGN853 has been evaluated in a phase $1 \mathrm{ex}-$ pansion clinical study $[6,7]$ and is currently being evaluated in the Forward1 (NCT02631876) phase 3 clinical study, it is noteworthy that IMGN853 is not the only folate receptor targeting therapeutic approach currently evaluated in clinical trials $[8,9]$. Nonetheless, the antibody, with its high specificity and affinity towards $F R \alpha$, has limited distribution in normal human tissue $[10,11]$ and mainly targets the overexpression in epithelial ovarian cancer and non-small cell lung cancer [12, 13]. After endocytosis, the ADC releases its toxic payload inside the cell via lysosomal degradation of the antibody and disulfide reduction of the sulfo-SPDB linker. Following binding of DM4 to the microtubules, the targeted cancer cell undergoes mitotic arrest and cell death.

In order to improve the drug development process of novel therapeutic agents, it is becoming more and more important to concurrently develop companion diagnostics [14-16]. With this in mind, the aim of this study was to develop and evaluate an ${ }^{89} \mathrm{Zr}$-labeled antibody derived from the FR $\alpha$-targeting antibody, M9346A, as an immuno-positron emission tomography (immuno-PET) companion diagnostic agent for the antibody-drug conjugate IMGN853 that is based on the same humanized antibody (Fig. 1). In order to develop a M9346A-based PET imaging agent, we asked the following questions: (1) Is it possible to achieve the immunoreactivity after modification with desferrioxamine (DFO) as a chelator and radiolabeling with $\mathrm{Zr}$-89? (2) Is this antibody-based PET imaging agent able to delineate ovarian cancer xenografts? (3) Does the pharmacokinetics of the radiopharmaceutical match with the pharmacokinetic profile of the antibody-drug-conjugate? (4) Can we predict antibody-drug conjugate success using the novel companion diagnostic?

\section{Methods}

\section{Materials}

Unless otherwise stated, all chemicals and solvents were used without further purification. Water used for this study was ultrapure $\left(>18.2 \mathrm{M} \Omega \mathrm{cm}^{-1}\right.$ at $\left.25{ }^{\circ} \mathrm{C}\right)$. Phosphate-buffered saline (PBS) as well as cell growth medium was purchased from the Media Preparation Facility at Memorial Sloan Kettering Cancer Center (MSK)
(New York, NY). Humanized monoclonal antibody recognizing FR $\alpha$ and M9346A, as well as antibodydrug-conjugate IMGN853 were provided by ImmunoGen, Inc. (Waltham, MA) and further purified via a PD10 desalting column (GE Healthcare). Concentrations of solutions containing antibody were determined by using a NanoDrop ${ }^{\text {Tw }} 2000$ spectrophotometer from Thermo Fisher Scientific (Waltham, MA). The bifunctional chelator $p$-isothiocyanatobenzyl-desferrioxamine (DFO-Bz-NCS) was purchased from Macrocycles (Plano, TX). ${ }^{89} \mathrm{Zr}$-oxalate was acquired from 3D Imaging, LLC (Maumelle, AR). HPLC reactions $(1.0 \mathrm{~mL} / \mathrm{min}$, phosphate -buffered saline) were performed on a Shimadzu UFLC HPLC system equipped with a DGU-20A degasser, a SPD-M20A UV detector, a LC-20AB pump system, and a
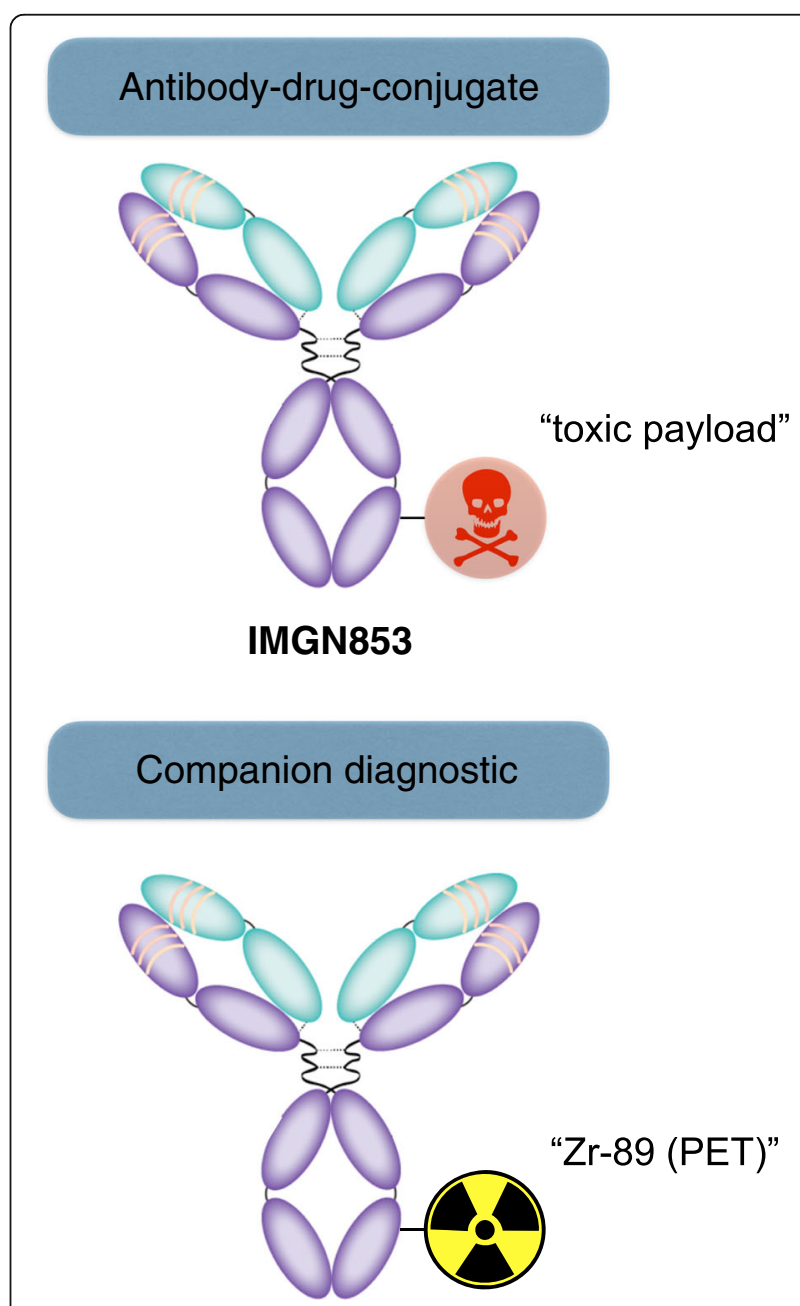

\section{[89Zr]Zr-DFO-M9346A}

Fig. 1 Concept of an antibody-based companion diagnostic for cancer therapy using positron emission tomography (PET) imaging. The humanized antibody, M9346A, functions as targeting vector for antibody-drug-conjugate as well as companion diagnostic 
CBM-20A communication BUS module using a size exclusion column (GE Superdex ${ }^{\mathrm{Tt}}$ 200, 10/300 GL).

\section{Functionalization and radiolabeling of antibody M9346A} The humanized antibody, M9346A, was functionalized with the bifunctional chelator $p$-isothiocyanatobenzyl-desferrioxamine (DFO-Bz-NCS) with a 1:3.5 antibody:DFO ratio, as previously described $[17,18]$. Specifically, a solution of previously purified antibody M9346A $(500 \mu \mathrm{L}$, $2.27 \mathrm{mg}$ ) in $\mathrm{PBS}$ was adjusted to $\mathrm{pH}=8.5$ with $1 \mathrm{M}$ $\mathrm{Na}_{2} \mathrm{CO}_{3}(1.0 \mu \mathrm{L})$. Then, a solution of DFO-Bz-NCS $(4.2 \mathrm{mM}, 4.0 \mu \mathrm{L})$ in dimethylsulfoxide was slowly added and the reaction mixture was incubated at $37{ }^{\circ} \mathrm{C}$ for $90 \mathrm{~min}$. Afterwards, the DFO-modified antibody was purified using a PD-10 desalting column and isolated in PBS solution for in vitro and in vivo studies.

A solution of ${ }^{89} \mathrm{Zr}$-oxalate in $1 \mathrm{M}$ oxalic acid $(5.0 \mu \mathrm{L}$, $85.1 \mathrm{MBq}, 2.3 \mathrm{mCi}$ ) was added to phosphate-buffered saline $(100 \mu \mathrm{L})$, and a $1 \mathrm{M}$ sodium carbonate solution $(4.8 \mu \mathrm{L})$ was used to adjust the $\mathrm{pH}$ to 7.1-7.4. Then, a solution of DFO-M9346A (500 $\mu \mathrm{L}, 500 \mu \mathrm{g})$ was added to the neutralized $\mathrm{Zr}-89$ solution and the reaction mixture was incubated at $37^{\circ} \mathrm{C}$ for $1 \mathrm{~h}$. After purification using PD-10 desalting columns (GE Healthcare), $\left.{ }^{89} \mathrm{Zr}\right] \mathrm{Zr}$-DFO-M9346A (85.7 \pm $5.7 \%$ isolated radiochemical yield and $3.08 \pm 0.43 \mathrm{mCi} / \mathrm{mg}$ specific activity) was isolated in a PBS solution $(2.0 \mathrm{~mL})$ and radiochemical purity $(98.0 \pm 0.7 \%)$ was determined through radio-instant thin/layer chromatography. Then, the resulting ${ }^{89} \mathrm{Zr}$-radiolabeled antibody solution was diluted with PBS to the desired volume for in vitro and in vivo studies.

\section{Cancer cell lines}

We chose four cancer cell lines with variable FR $\alpha$ expression levels to correlate imaging findings. The HeLa-derived cancer cell line KB (high expression), the ovarian cancer cell line OV90 (low/medium expression), the human lung cancer cell line H2110 (low/medium), and the human lung cancer cell line A549 (low/no expression) were purchased from ATCC (Manassas, VA). No further cell line authentication was conducted, and the cell lines were expended by passaging 2-3 times, aliquoted, and frozen in liquid nitrogen. For use in in vitro as well as in vivo experiments, the cell lines were grown in medium recommended by American Type Culture Collection (ATCC) and passaged regularly at $70-80 \%$ confluence every 3-4 days. All cell lines were cultured at $37^{\circ} \mathrm{C}$ and $5 \%$ carbon dioxide.

\section{Characterization and in vitro experiments}

$\left[{ }^{89} \mathrm{Zr}\right] \mathrm{Zr}$-DFO-M9346A was investigated for stability by incubating the radioligand in $1 \%$ bovine serum albumin at $37{ }^{\circ} \mathrm{C}$ for 3 days. Therefore, radiochemical purity of $\left[{ }^{89} \mathrm{Zr}\right] \mathrm{Zr}$-DFO-M9346A was tested at various time points via radio-instant thin layer chromatography (Eckert \& Ziegler, Germany) with ethylendiaminetetraacetic acid $(50 \mathrm{mM})$ as mobile phase.

A Lindmo assay [19] was performed to validate the integrity of the ${ }^{89} \mathrm{Zr}$-radiolabeled antibody M9346A. In detail, serial dilutions of $\mathrm{KB}$ cells were incubated with one concentration of $\left[{ }^{89} \mathrm{Zr}\right] \mathrm{Zr}$-DFO-M9346A in Eppendorf vials $(1.5 \mathrm{~mL})$ on a shaking rack. After incubation at room temperature for $1 \mathrm{~h}$, cells were washed with ice-cold PBS and the retained radioactivity on cells was measured using a WIZARD ${ }^{2}$ automatic $\gamma$-counter from PerkinElmer.

Furthermore, an in vitro binding assay was performed with cell lines expressing different levels of $F R \alpha$, as previously described [20]. One day prior to the in vitro experiment, the cells lines KB, OV90, and H2110, as well as A549 (each $1.0 \times 10^{6}$ cells per well, $>90 \%$ viability for each cell line) were seeded into 6-well plates containing growth medium $(2.0 \mathrm{~mL})$ and incubated at $37^{\circ} \mathrm{C}$ to form subconfluent cell monolayers. Then, growth medium was removed from the 6-well plates, cells were washed with PBS, and $900 \mu \mathrm{L}$ of growth medium was added. After $1 \mathrm{~h}$ of incubation at $37{ }^{\circ} \mathrm{C}$, a solution of $\left[{ }^{89} \mathrm{Zr}\right] \mathrm{Zr}$-DFO-M9346A $(0.5 \mu \mathrm{Ci}, 100 \mathrm{ng})$ in PBS $(100 \mu \mathrm{L})$ was added to the wells. For blocking studies, cells were pre-incubated with humanized antibody M9346A $(10 \mu \mathrm{g}) 5 \mathrm{~min}$ prior to the addition of ${ }^{89} \mathrm{Zr}$-radiolabeled antibody $(0.5 \mu \mathrm{Ci}, 100 \mathrm{ng})$. To determine the number of cells at the time of the experiment, a separate set $(n=3)$ of wells for each cell line and experiment was analyzed by detaching the cells with trypsin and counted immediately using a Vi-cell XR cell viability analyzer (Beckman Coulter). After $1 \mathrm{~h}$ post-incubation at $37{ }^{\circ} \mathrm{C}$, the supernatant of each well was collected together with washing solution of ice-cold PBS. Then, cells were lysed with sodium hydroxide solution $(1 \mathrm{M}, 1.0 \mathrm{~mL})$ for $5 \mathrm{~min}$ at room temperature. Finally, each cell suspension was collected and all radioactive samples were measured using a WIZARD ${ }^{2}$ automatic $\gamma$-counter from PerkinElmer (Waltham, MA). Receptor-specific uptake was determined by correlating cell-bound activity relative to non-bound activity in the supernatant and displayed as a percentage of applied activity per $5.0 \times 10^{5}$ cells.

\section{Animals}

All in vivo studies and procedures were performed in accordance with an approved protocol from the Institutional Animal Care and Use Committee at MSK. All in vivo experiments were carried out in female, athymic nude mice (Envigo; outbread; 6-8 weeks, 20-25 g). Subcutaneous KB and OV90 xenografts $\left(150 \pm 20 \mathrm{~mm}^{3}\right)$ were established as previously described $[5,20]$. In detail, suspended KB cells $\left(1.5 \times 10^{6}\right.$, viability $\left.>93 \%\right)$ or suspended OV90 cells $\left(1.0 \times 10^{7}\right.$, viability: $\left.>95 \%\right)$ in a 
solution containing a 1:1 mixture of Matrigel (Becton Dickinson, Bedford, MA) and cell culture media (no FBS for OV90 xenografts) were subcutaneously inoculated on the right shoulder of anesthetized mice (1.5-2.0\% isoflurane (Baxter Healthcare) in medical air $(2 \mathrm{~L} / \mathrm{min})$ ). Prior in vivo studies, KB tumors were grown for 910 days post-implantation and OV90 tumors were grown for 21 days.

\section{In vivo $\mathrm{PET} / \mathrm{CT}$ imaging and biodistribution}

For in vivo studies, PET images were recorded using a small-animal Inveon ${ }^{\bullet}$ PET/CT system from Siemens (Knoxville, TN) and mice were anesthetized with 1.5$2.0 \%$ isoflurane at $2.0 \mathrm{~L} / \mathrm{min}$ flow of medical air. PET images were analyzed using AsiPro $\mathrm{VM}^{\mathrm{mm}}$ software (Concorde Microsystems) and Inveon research workplace 4.1 software (Siemens Healthcare). For biodistribution studies, mice were euthanized at pre-determined time points through asphyxiation with carbon dioxide and organs of interest were collected, weighed, and counted using a WIZARD ${ }^{2}$ automatic $\gamma$-counter from PerkinElmer. The percentage of tracer uptake stated as percentage injected activity per gram of tissue (\%IA/g) was calculated as the activity associated with tissue per organ weight per actual injected dose, decay corrected to the start time of counting. KB tumor-bearing mice ( $n$ = 10) were injected with $\left[{ }^{89} \mathrm{Zr}\right] \mathrm{Zr}$-DFO-M9346A $(7.75 \pm$ $0.25 \mathrm{MBq}, 209.0 \pm 6.7 \mu \mathrm{Ci}, 50 \mu \mathrm{g})$ in PBS $(200 \mu \mathrm{L})$. PET images were acquired at $4 \mathrm{~h}, 24 \mathrm{~h}, 48 \mathrm{~h}$, and $72 \mathrm{~h}$ post-injection, and biodistribution studies were performed at $24 \mathrm{~h}$ and $72 \mathrm{~h}$ (each cohort, $n=5$ ). OV90 tumor-bearing mice $(n=6)$ were injected with $\left[{ }^{89} \mathrm{Zr}\right] \mathrm{Zr}$-DFO-M9346A $(2.02 \pm 0.08 \mathrm{MBq}, 48.4 \pm 2.0 \mu \mathrm{Ci}$, $50 \mu \mathrm{g})$ in PBS $(200 \mu \mathrm{L})$. PET images were acquired at $24 \mathrm{~h}$ and $48 \mathrm{~h}$ post-injection, and biodistribution studies were performed at $24 \mathrm{~h}$ and $48 \mathrm{~h}$ post-injection of radioligand. Each tumor-bearing cohort exhibited expected bone uptake upon release of $\mathrm{Zr}-89$ from the chelator desferrioxamine (DFO) of about 5-10 \% IA/g.

\section{Radiolabeling of $A D C$}

All iodine-131 radiolabeling reactions were performed in pre-coated Iodogen (1,3,4,6-tetrachloro-3 $\alpha, 6 \alpha$-diphenyl glycoluril) tubes (100 $\mu \mathrm{g}$ per tube). For instance, an aqueous solution of $\mathrm{Na}^{131} \mathrm{I}(37.0 \mathrm{MBq}, 1.0 \mathrm{mCi})$ was added to a phosphate buffered saline solution of IMGN853 $(250 \mu \mathrm{g}$, $45 \mu \mathrm{L}$ ) and the tube containing the reaction mixture was gently agitated at 1-min intervals at room temperature over a period of $10 \mathrm{~min}$. After purification using PD-10 desalting columns, $\left.{ }^{[131} \mathrm{I}\right]$-IMGN853 $(32.1 \mathrm{MBq}, 0.87 \mathrm{mCi})$ was isolated in $87 \%$ radiochemical yield and high radiochemical purity (99.9\%).

\section{Blood half-life studies}

Female athymic nude mice (6-8 weeks, $n=5)$ were injected intravenously with $\left[{ }^{89} \mathrm{Zr}\right] \mathrm{Zr}$-DFO-M9346A (2.3 $\pm 0.2 \mathrm{MBq}, 62.6 \pm 4.6 \mu \mathrm{Ci}, 25 \mu \mathrm{g})$ or $\left[{ }^{131} \mathrm{I}\right]-\mathrm{IMGN} 853$ $(2.7 \pm 0.1 \mathrm{MBq}, 73.4 \pm 2.6 \mu \mathrm{Ci}, 25 \mu \mathrm{g})$. At predetermined time points $(0.5 \mathrm{~h}, 1.0 \mathrm{~h}, 3.0 \mathrm{~h}, 6.0 \mathrm{~h}, 24 \mathrm{~h}, 48 \mathrm{~h}$, and $72 \mathrm{~h}$ ), a sample of blood was obtained from the great saphenous vein of each animal in a heparin-coated capillary glass tube and the weights of the collected blood samples were obtained by using an analytical balance Toledo XS105 from Mettler. The radioactivity of the blood samples was recorded with a WIZARD ${ }^{2}$ automatic $\gamma$-counter from PerkinElmer. The residual radiotracer, expressed as a percentage injected dose per gram (\%IA/ $\mathrm{g}$ ), was calculated as the activity present in the blood weighed per actual injected dose, decay corrected to the time of counting.

\section{Biodistribution studies}

For biodistribution studies, OV90 tumor-bearing nude mice (6-8 weeks, $n=5)$ were injected intravenously with $\left[{ }^{131} \mathrm{I}\right]$-IMGN853 $(1.42 \pm 0.02 \mathrm{MBq}, 38.3 \pm 0.4 \mu \mathrm{Ci})$ in PBS $(200 \mu \mathrm{L})$. At $48 \mathrm{~h}$ post-injection, mice were euthanized and organs of interest were collected, weighed, and counted with a WIZARD ${ }^{2}$ automatic $\gamma$-counter from PerkinElmer.

\section{In vivo therapy studies}

Tumor volumes for all mice were measured via manual caliper measurements of the longest dimension $(x)$, shortest dimension $(y)$, and height $(\mathrm{z})$, assuming an ellipsoid shape $\left(V=(3.1415 / 6) \times(\mathrm{x} \times \mathrm{y} \times \mathrm{z})\left[\mathrm{mm}^{3}\right]\right)$. During tumor measurements, weight for all mice was recorded, and after initial tumor measurements, mice were randomized into three cohorts $(n=3-5)$ per cohort ensuring all cohorts had tumor volumes of $150-200 \mathrm{~mm}^{3}$. One day after initial tumor volume measurements, mice in the therapy cohort A were co-administered with a solution of ADC $(1.25 \mathrm{mg} / \mathrm{kg}, 31.2 \mu \mathrm{g})$ and companion imaging agent $\left[{ }^{89} \mathrm{Zr}\right] \mathrm{Zr}$-DFO-M9346A $(3.34 \pm 0.04 \mathrm{MBq}, 90.3 \pm 1.1 \mu \mathrm{Ci}$, $25 \mu \mathrm{g})$ in PBS $(200 \mu \mathrm{L})$. Cohort B was injected with the companion imaging agent $\left.{ }^{89} \mathrm{Zr}\right] \mathrm{Zr}$-DFO-M9346A (3.68 \pm $0.07 \mathrm{MBq}, 99.5 \pm 1.8 \mu \mathrm{Ci}, 25 \mu \mathrm{g})$. Cohort $\mathrm{C}$ was injected with PBS $(200 \mu \mathrm{L})$. Two days after administration, mice of cohort A and cohort B were anesthetized with 1.5-2.0\% isoflurane at $2.0 \mathrm{~L} / \mathrm{min}$ flow of medical air and PET/CT imaging was accomplished over $10 \mathrm{~min}$ using small-animal Inveon ${ }^{\circ} \mathrm{PET} / \mathrm{CT}$ system from Siemens (Knoxville, $\mathrm{TN})$. Then, tumor volumes were determined via caliper measurement every 3 to 4 days up to an endpoint volume of $>1000 \mathrm{~mm}^{3}$. Additionally, all mice were assessed twice per week throughout the study for outward signs of toxicity and decreasing body weight. 


\section{Results}

\section{Development of $\left[{ }^{89} \mathrm{Zr}\right] \mathrm{Zr}$-DFO-M9346A}

Modification of the humanized monoclonal antibody (mAb), M9346A, with the bifunctional chelator DFO-Bn-NCS was accomplished using a previously reported method (Fig. 2a, Additional file 1: Figure S1) [17, 18, 21]. First, desferrioxamine was coupled to lysine- $\mathrm{NH}_{2}$ groups of the parent antibody (1:3.5 antibody: DFO ratio) at $\mathrm{pH}=8.5$ over $90 \mathrm{~min}$ in phosphate buffered saline, followed by purification using PD-10 desalting columns. Subsequently, radiolabeling of the modified $\mathrm{mAb}$ with neutralized $\left.{ }^{89} \mathrm{Zr}\right] \mathrm{Zr}$-oxalic acid solution proceeded in PBS at $37^{\circ} \mathrm{C}$ over $60 \mathrm{~min}$, followed by purification using PD-10 desalting columns. DFO-M9346A was radiolabeled reliably with good specific activity (3.08 \pm $0.43 \mathrm{mCi} / \mathrm{mg}$ ) and radiochemical purity $(98.0 \pm 0.7 \%)$. Lindmo assays of the resulting radiolabeled antibody construct confirmed that the immunoreactivity of the construct was established through binding of the antibody to FR $\alpha$ in vitro $(83.4 \pm 3.5 \%$, Additional file 2: Figure S2). Stability of $\left[{ }^{89} \mathrm{Zr}\right] \mathrm{Zr}$-DFO-M9346A was examined in bovine serum albumin at $37{ }^{\circ} \mathrm{C}$ over a period of $72 \mathrm{~h}$ and showed that more than $95 \%$ of the radioligand remained intact (Additional file 3: Figure S3). Further characterization of $\left[{ }^{89} \mathrm{Zr}\right] \mathrm{Zr}$-DFO-M9346A included an in vitro cell uptake assay using cancer cell lines with various expression levels of FR $\alpha$ (Fig. 2c). We observed highly specific cell-associated uptake and retention in $\mathrm{KB}$, OV90, and $\mathrm{H} 2110$ after $1 \mathrm{~h}$ of incubation at $37{ }^{\circ} \mathrm{C}(43.9 \pm 0.9 \%, 17.6 \pm$ $0.5 \%$, and $17.3 \pm 0.8 \%$, per 500,000 cells respectively), corresponding to their folate receptor expression levels [5]. The cancer cell line A549 with very low expression levels of FR $\alpha$ displayed negligible uptake $(0.4 \pm 0.1 \%)$.

\section{In vivo and ex vivo experiments with [ $\left.{ }^{89} \mathrm{Zr}\right] \mathrm{Zr}$-DFO-} M9346A in subcutaneous epithelial cancer xenografts We first asked whether $\left[{ }^{89} \mathrm{Zr}\right] \mathrm{Zr}$-DFO-M9346A can target a tumor in vivo known to be high in expression of FR $\alpha$ (Fig. 3a and Additional file 4: Figure S4). After tail vein injection of the radioligand, small-animal PET imaging $(4 \mathrm{~h}, 24 \mathrm{~h}, 48 \mathrm{~h}$, and $72 \mathrm{~h}$ ) and biodistribution studies ( $24 \mathrm{~h}$ and $72 \mathrm{~h}$ ) were conducted using KB tumor-bearing mice (female, athymic, $n=10$ ). Serial PET imaging showed clear delineation of the tumor already after $24 \mathrm{~h}$ with low uptake in normal tissue. The maximum intensity projections (MIPs) indicated that blood-pool and background activity cleared over time, leading to improved tumor-to-background ratios at $48 \mathrm{~h}$ post-injection. Ex vivo biodistribution data corroborated the PET data, as high tumor localization of $\left[{ }^{89} \mathrm{Zr}\right.$ ] Zr-DFO-M9346A at $24 \mathrm{~h}$ (30.1 $\pm 1.9 \% \mathrm{IA} / \mathrm{g}, \quad n=5$ ) was observed and tumor uptake a

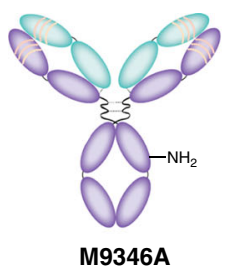

1) $\mathrm{p}-\mathrm{SCN}-\mathrm{Bn}-\mathrm{DFO}$ $\mathrm{pH}=8.5,37^{\circ} \mathrm{C}, 90 \mathrm{~min}$

2) $89 \mathrm{Zr}$-oxalate $\mathrm{pH}=8.3,37^{\circ} \mathrm{C}, 60 \mathrm{~min}$

b

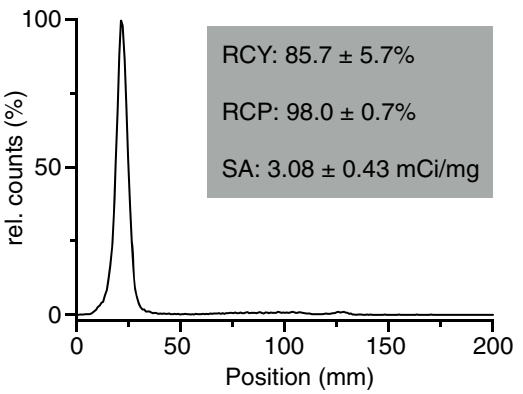

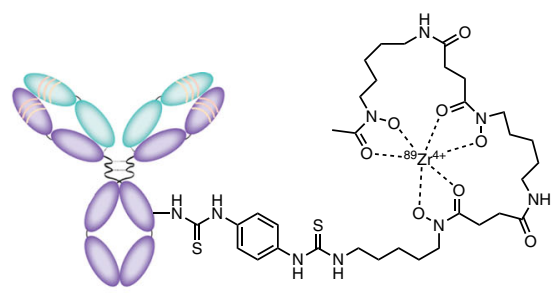

[89Zr]Zr-DFO-M9346A

C

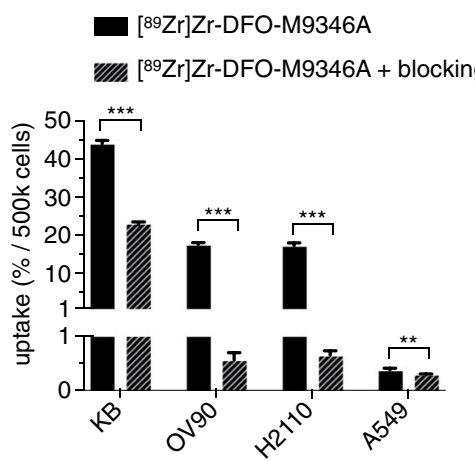

Fig. 2 Synthesis and characterization of ${ }^{89}{ }^{Z}$ r]Zr-DFO-M9346A. a Conjugation of $p$-isothiocyanatobenzyl-desferrioxamine (DFO-Bz-NCS) to humanized antibody M9346A in basic aqueous conditions at $37^{\circ} \mathrm{C}$ for $90 \mathrm{~min}$ and ${ }^{89} \mathrm{Zr}$-radiolabeling of DFO-M9346A at $37^{\circ} \mathrm{C}$ for 60 min. b After purification of reaction mixture using a PD-10 desalting column, quality control of $\left.{ }^{89} \mathrm{Zr}\right] \mathrm{Zr}$-DFO-M9346A was performed using radio-instant thin layer chromatography in a solution of EDTA $(50 \mathrm{mM})$. c In vitro uptake studies of either $\left[{ }^{89} \mathrm{Zr}\right] \mathrm{Zr}$-DFO-M9346A (100 ng) or a mixture of $\left[^{89} \mathrm{Zr}\right] \mathrm{Zr}$ DFO-M9346A (100 ng) and M9346A (10 $\mu \mathrm{g})$ using cancer cell lines KB, OV90, H2110, and A549 with various expression levels of FRa. ${ }^{* * P}$ $<0.01 ;{ }^{* *} P<0.001$. Error bars represent the SD 
a
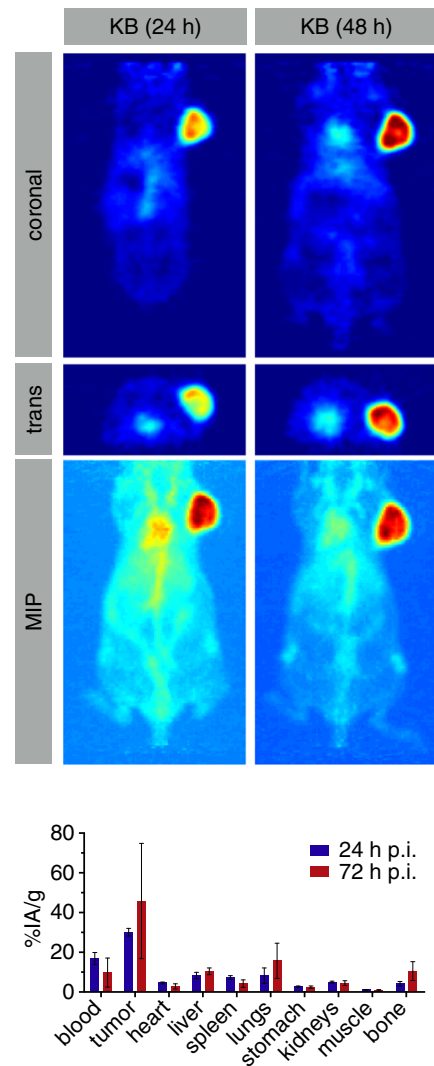

b
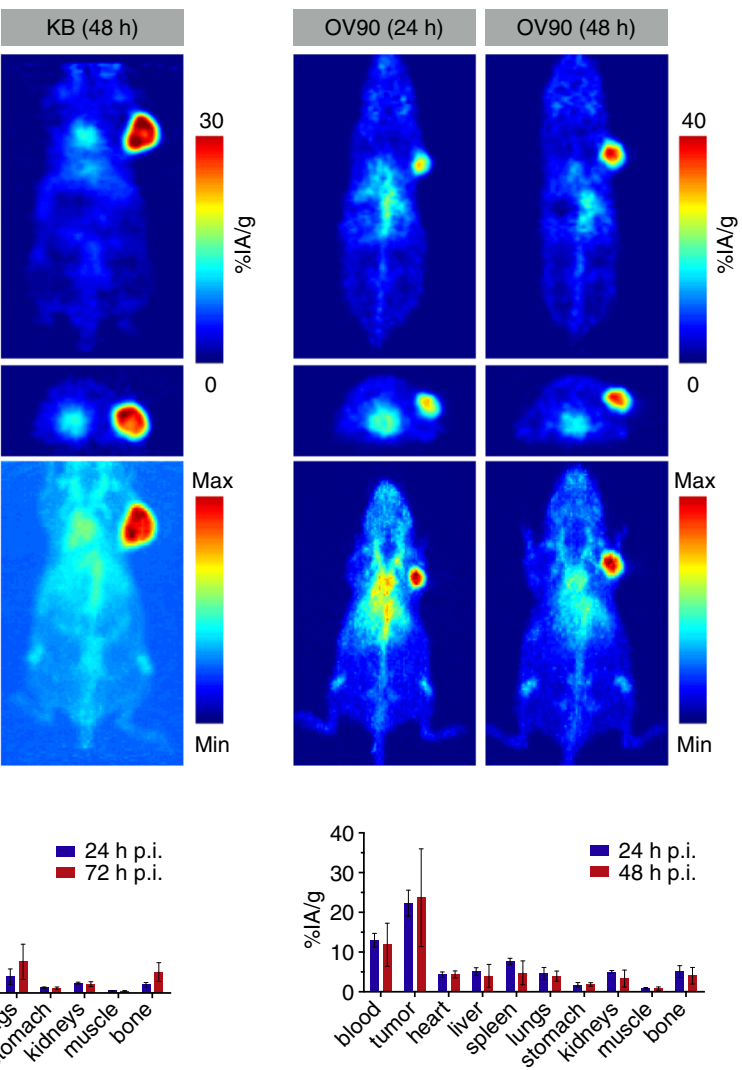

Fig. 3 In vivo studies of [ ${ }^{89} \mathrm{Zr}$ ZZr-DFO-M9346A: a PET images acquired at $24 \mathrm{~h}$ and $48 \mathrm{~h}$ post-injection and biodistribution studies performed at $24 \mathrm{~h}$ and $72 \mathrm{~h}$ with $\left[{ }^{89} \mathrm{Zr}\right] \mathrm{Zr}$-DFO-M9346A intravenously administered in KB tumor bearing mice. b PET images acquired at $24 \mathrm{~h}$ and $48 \mathrm{~h}$ postinjection and biodistribution studies performed at $24 \mathrm{~h}$ and $72 \mathrm{~h}$ with $\left.{ }^{89} \mathrm{Zr}\right] \mathrm{Zr}$-DFO-M9346A intravenously administered in tumor bearing mice

increased over time out to $72 \mathrm{~h}(45.8 \pm 29.0 \% \mathrm{IA} / \mathrm{g}, n=5)$ post-injection, suggesting an optimal time point for future PET imaging studies without increasing bone uptake over time (Additional file 5: Figure S5).

After the first proof-of-concept experiment using $\mathrm{KB}$ cells, we set out to validate $\left[{ }^{89} \mathrm{Zr}\right] \mathrm{Zr}$-DFO-M9346A in a more clinically relevant cancer model using the ovarian cancer cell line OV90. To this end, $\left.{ }^{89} \mathrm{Zr}\right] \mathrm{Zr}$-DFO-M9346A was intravenously injected into female athymic nude mice bearing a subcutaneous OV90 xenograft on the right shoulder. PET imaging and ex vivo biodistribution after $24 \mathrm{~h}$ and $48 \mathrm{~h}$ confirmed efficient retention of the radioligand in the tumor $(24.2 \pm 6.3 \% \mathrm{IA} / \mathrm{g}, n=$ 6) with very limited background uptake (Fig. $3 \mathrm{~b}$ and Additional file 6: Figure S6).

\section{Pharmacokinetic head-to-head comparison between IMGN853 and [ $\left.{ }^{89} \mathrm{Zr}\right] \mathrm{Zr}$-DFO-M9346A}

After successful characterization of the antibody-based PET imaging agent showing very promising performance in vivo, we next set out to validate that the antibody-drug conjugate and companion diagnostic show nearly identical pharmacokinetic profiles. In order to achieve this goal, we performed a head-to-head comparison between both antibody constructs. In order to do that, we radiolabeled the antibody-drug conjugate, IMGN853, through direct halogenation with I-131 (Fig. 4a). [ $\left.{ }^{131} \mathrm{I}\right]$-IMGN853 was isolated in good isolated radiochemical yields $(86.7 \pm 13.5 \%)$ and high radiochemical purity $(99.3 \pm 0.7 \%)$. Based on previous in vitro studies with $\left[{ }^{89} \mathrm{Zr}\right] \mathrm{Zr}$-DFO-M9346A, we tested whether the radiolabeled $\mathrm{ADC}$ retains its ability to bind to $\mathrm{FR} \alpha$ and performed an in vitro uptake with using $\mathrm{KB}$ cells (Fig. 4b). Then, we went ahead and compared the drugs' pharmacokinetic behavior by evaluating each tracer's blood half-life in vivo. Figure 4c shows the correlation of tracer $(\% \mathrm{IA} / \mathrm{g})$ in the blood at predetermined time points. The blood half-life for both radioligands was determined through serial bleeds in healthy mice, and the obtained data points were compared to each other. We found a good correlation between $\left[{ }^{131} \mathrm{I}\right]$-IMGN853 and $\quad\left[{ }^{89} \mathrm{Zr}\right] \mathrm{Zr}$-DFO-M9346A $\quad\left(R^{2}=0.9736\right) . \quad$ Ex vivo 


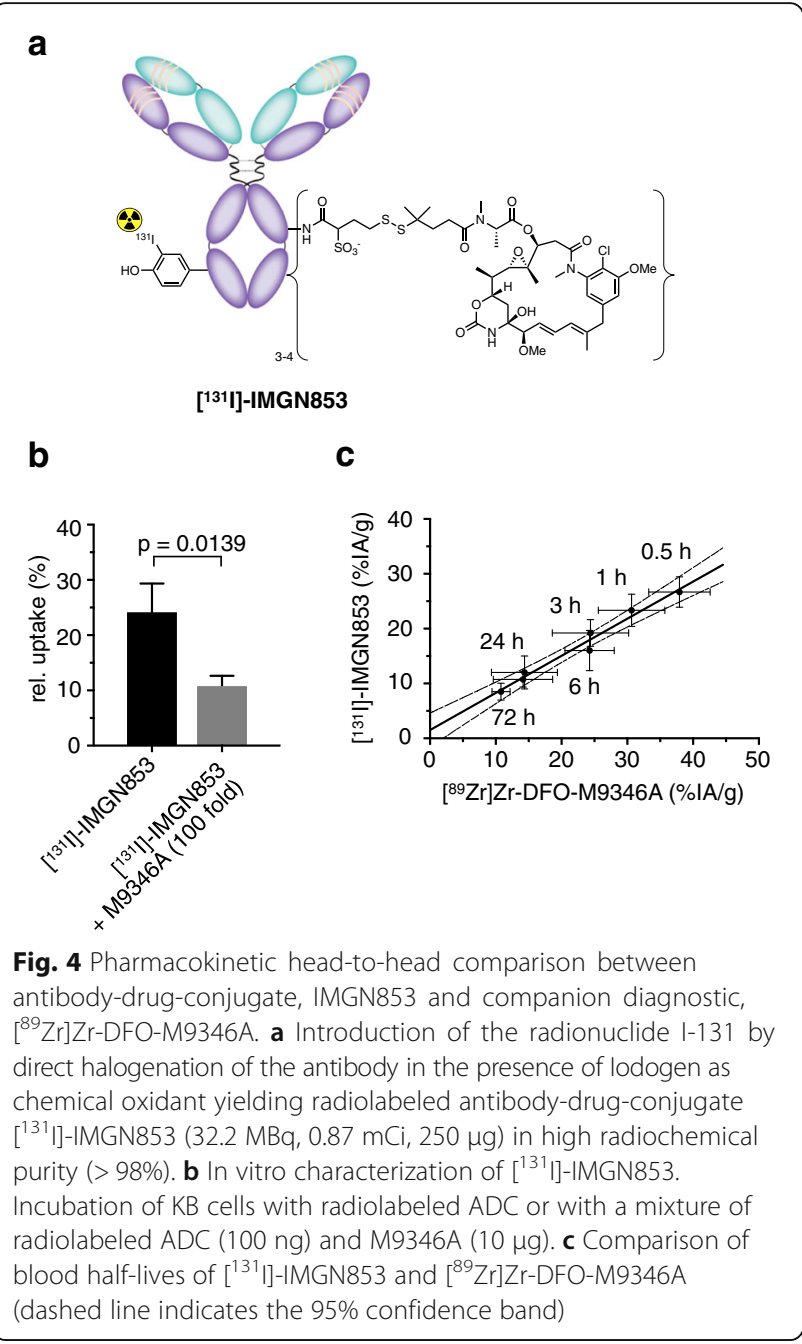

biodistribution data revealed very similar biodistribution pattern in all organs compared to the companion diagnostic with slightly lower tumor uptake of $\left[{ }^{131} \mathrm{I}\right]$-IMGN853 of $17.3 \pm 5.2 \% \mathrm{IA} / \mathrm{g}$ (Additional file 7: Figure S7).

\section{Leveraging PET imaging with $\left[{ }^{89} \mathrm{Zr}\right] \mathrm{Zr}$-DFO-M9346A during therapy with IMGN853}

Finally, we determined whether $\left[{ }^{89} \mathrm{Zr}\right] \mathrm{Zr}$-DFO-M9346A could be used as a companion diagnostic during ADC therapy to predict therapy outcome. For these experiments (Fig. 5a), mice bearing OV90 tumor xenografts were injected with an imaging dose of $\left[{ }^{89} \mathrm{Zr}\right] \mathrm{Zr}$ DFO-M9346A $(90.3 \pm 1.1 \mu \mathrm{Ci}, 25 \mu \mathrm{g})$ as well as with a therapy dose of IMGN853 $(1.25 \mathrm{mg} / \mathrm{kg}, 31.2 \mu \mathrm{g})$. PET images were acquired 2 days post-administration, and tumor volume of each mouse was tracked over several days until the end of the study. In general, administration of $\left[{ }^{89} \mathrm{Zr}\right] \mathrm{Zr}$-DFO-M9346A during ADC treatment with IMGN853 confirmed good tumoral uptake with high tumor-to-tissue contrast (Fig. 5b). After quantification of the acquired PET images, we observed differences in tumoral uptake with the lowest uptake of $42.4 \% \mathrm{IA} / \mathrm{g}$ and the highest of $61.6 \% \mathrm{IA} / \mathrm{g}$. Following the tumor volume of individual mice revealed a differential response in ADC treatment (Fig. 5c). At 6 weeks post-treatment, two mice of the therapy cohort receiving IMGN853 $(1.25 \mathrm{mg} / \mathrm{kg})$ responded by inhibited tumor growth, whereas three mice showed similar tumor growth curves as the cohorts injected with $\left.{ }^{89} \mathrm{Zr}\right] \mathrm{Zr}$-DFO-M9346A (positive control) and PBS (negative control). No weight losses were observed in any cohort of the therapy study (Additional file 8: Figure S8). Correlation between tumoral uptake (\%IA/g) of $\left.{ }^{89} \mathrm{Zr}\right] \mathrm{Zr}$-DFO-M9346A and therapy outcome shows that in this cohort, mice with uptake greater than $50 \% \mathrm{IA} / \mathrm{g}$ appeared to be responders and mice with lower than $50 \% \mathrm{IA} / \mathrm{g}$ were non-responders (Fig. 5d). The cutoff level at $50 \% \mathrm{IA} / \mathrm{g}$ was arbitrarily set and corresponds to the average tumor uptake of $\left[{ }^{89} \mathrm{Zr}\right] \mathrm{Zr}$-DFO-M9346A in this cohort.

\section{Discussion}

Over the last decades, companion diagnostic agents have become more and more important in the development process of targeted drugs, particularly in oncology [14-16, 22]. Especially, nuclear medicine-based companion diagnostics targeting cancer-specific membrane bound receptors have received considerable attention [23-26]. In this study, we report a nuclear medicine-based companion diagnostic, [ ${ }^{89} \mathrm{Zr}$ ]Zr-DFO-M9346A, for the ADC mirvetuximab soravtansine (IMGN853). Currently, patient selections in clinical trials of IMGN853 are based on immunohistochemical (IHC) assessment of archival tumor tissue. Expression levels of FR $\alpha$ are not contemporaneous, and both intra- and inter-lesion tissue sampling is limited, making a non-invasive whole body imaging approach more favorable.

Following published protocols $[17,18]$, we were able to modify and radiolabel the FR $\alpha$-targeting antibody M9346A in good radiochemical yields $(88 \pm 5 \%)$ and high-specific activities $(3.08 \pm 0.43 \mathrm{mCi} / \mathrm{mg})$. $\left[{ }^{89} \mathrm{Zr}\right] \mathrm{Zr}$-DFO-M9346A was highly stable in human plasma ( $>97 \%$ at $24 \mathrm{~h}$ ). It also displayed relatively high immunoreactivity $(>80 \%)$ indicating conservation of the ability to bind to FR $\alpha$ in vitro. Furthermore, we observed high uptake in KB, OV90, and H2110 cells $(43.9 \pm 0.9 \%, 17.6 \pm 0.5 \%$, and $17.3 \pm 0.8 \%$, per 500,000 cells respectively). Co-incubation of OV90 and H2110 with a 100-fold excess of antibody M9346A further corroborates specific uptake. In case of the KB cancer cell line, incomplete blocking may be a result of the high abundance of FR $\alpha$ per cell in comparison to the other FR $\alpha$-positive cancer cell lines [27]. Nevertheless, reduction in uptake was statistically significant $(p<0.001)$. Binding to A549 was 


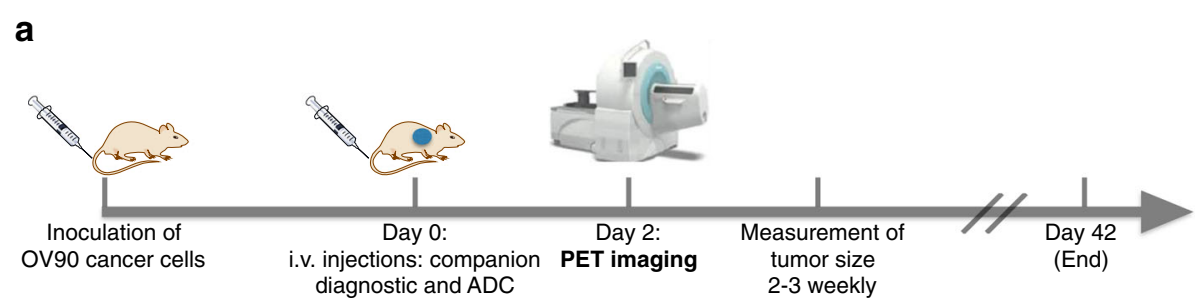

b
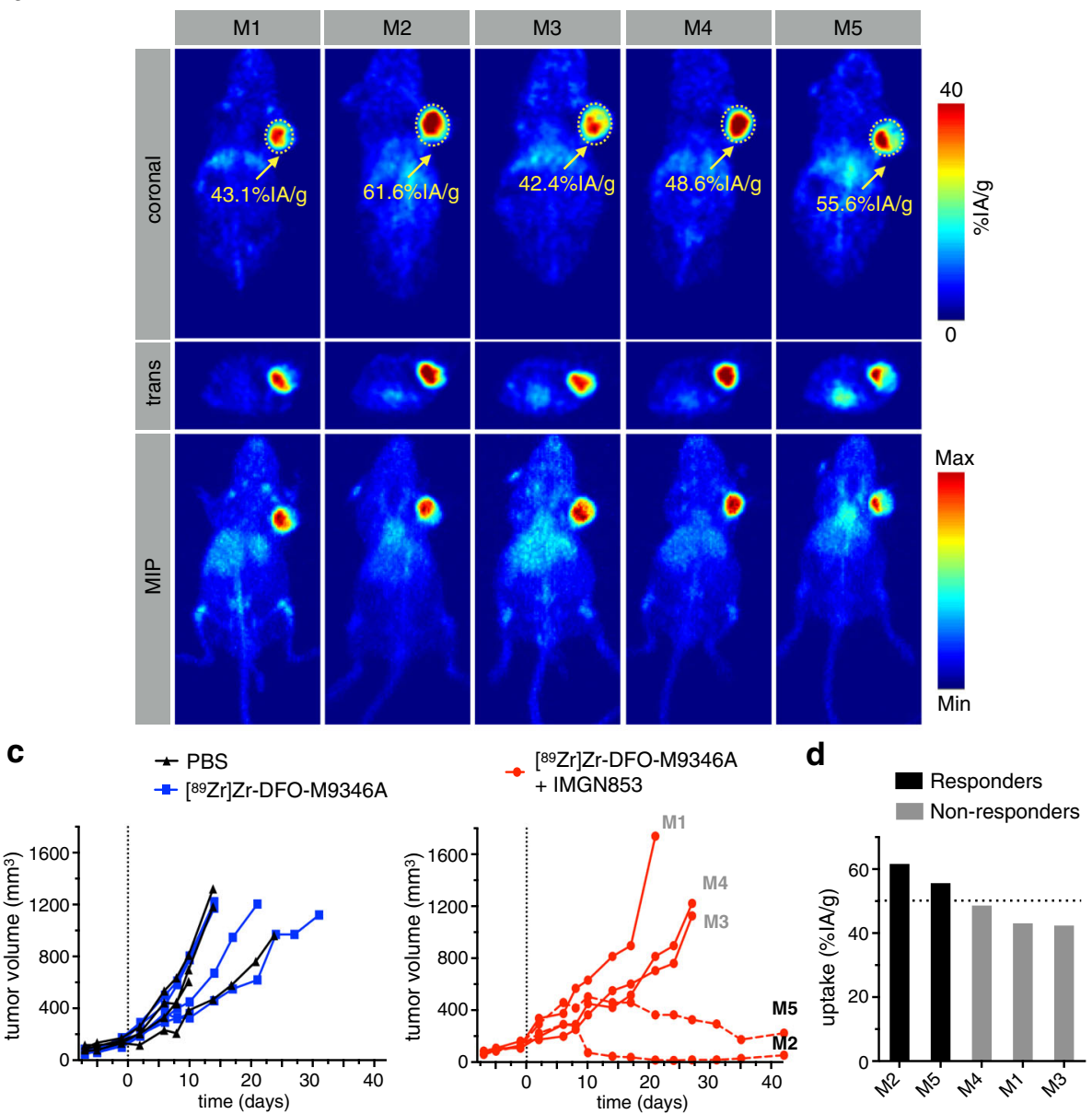

Fig. 5 Therapy study with antibody-drug-conjugate, IMGN853, and companion diagnostic, $\left.{ }^{89} \mathrm{Zr}\right] \mathrm{Zr}$-DFO-M9346A, using OV90 xenografts. a Overall design of the therapy study including inoculation of cancer cells, injection of ADC and companion diagnostic, PET imaging after 2 days, and continuously measuring tumor growth. b PET images of mice injected with ${ }^{89} \mathrm{Zr}$ ZZr-DFO-M9346A (90.3 $\left.\pm 1.1 \mu \mathrm{Ci}, 25 \mu \mathrm{g}\right)$ and IMGN853 (1.25 mg/ $\mathrm{kg}, 31.2 \mu \mathrm{g}$ ) and quantification through ROI analysis of coronal slices. c Plot of the individual tumor volume post treatment (days). $\mathbf{d}$ Correlation of tracer uptake $(\% \mathrm{IA} / \mathrm{g})$ and therapy outcome

negligible $(<1 \%)$, since FR $\alpha$ expression levels are reported to be low in comparison with other cancer lines.

Encouraged by the successful in vitro characterization of $\left.{ }^{89} \mathrm{Zr}\right] \mathrm{Zr}$-DFO-M9346A, we next sought to test the companion diagnostic in tumor-bearing mice. Initially, we injected the PET imaging agent in KB tumor bearing mice. Already $24 \mathrm{~h}$ after tracer administration, we observed good delineation of the tumor. According to the maximum-intensity-projection, slow blood clearance of the antibody construct caused accumulation in the heart region. However, qualitatively improved PET images were observed at $48 \mathrm{~h}$ and $72 \mathrm{~h}$ post-injection. Biodistribution data supported the results of the PET imaging studies, observing good anticipated tumor-to-blood ratios of 5.9 and tumor-to-bone ratios of 5.4 at $72 \mathrm{~h}$ post-administration of $\left.{ }^{89} \mathrm{Zr}\right] \mathrm{Zr}$-DFO-M9346A. In an OV90 tumor-bearing PET imaging study, we observed similar uptake patterns with good delineation of tumor and high imaging contrast. Based on the biodistribution studies, we reached slightly lower uptake of the 
companion diagnostic, which is likely due to the lower expression level of FR $\alpha$ in OV90 cells compared to KB cells.

We next wanted to set stage for being able to predict ADC therapy success using our new companion diagnostic. Both antibody-based constructs had similar pharmacokinetic profiles, similar to what we showed with a nanoparticle construct earlier [28]. Therefore, we were able to directly radiolabel the ADC with iodine-131. A standard in vitro uptake assay showed that binding as well as specificity of the antibody-based construct towards FR $\alpha$ was conserved, indicating minor modifications of the antibody. A direct comparison of the blood half-life of each radiolabeled antibody construct, $\left[{ }^{131} \mathrm{I}\right]$-IMGN853 and [ $\left.{ }^{89} \mathrm{Zr}\right] \mathrm{Zr}$-DFO-M9346A, successfully indicated nearly identical pharmacokinetic behaviors in vivo. Radioiodination of antibodies with Iodogen is a standard method, suggesting that it is very unlikely that labeling conditions will lead to degradation of IMGN853. Since the antibody exhibits a more than 20 -fold higher molecular weight in comparison with the added modifications (3-4 DM4 per antibody and 3-4 chelator per antibody), we expected minor alterations in the pharmacokinetics of each construct. However, other physiochemical properties such as polarity and charge of a molecule can influence drug pharmacokinetics as well.

We tested the ability of $\left.{ }^{89} \mathrm{Zr}\right] \mathrm{Zr}$-DFO-M9346A to predict FR $\alpha$-targeted therapy with IMGN853 in vivo. The penultimate goal of this study was to distinguish between responders and non-responders at the beginning of a therapeutic intervention-which might be an additional first step to improve the interpretation of current and future clinical trials using IMGN853. Two days post-co-administration of $\left[{ }^{89} \mathrm{Zr}\right] \mathrm{Zr}-\mathrm{DFO}-\mathrm{M} 9346 \mathrm{~A}$ and IMGN853 in OV90 tumor-bearing mice, we were able to delineate OV90 tumors, in which we observed heterogeneity of companion diagnostic, presumably dictated not only by target expression, but also tumor physiology [29]. By measuring the tumor volume of each animal over time, we were able to establish a threshold of tracer uptake at $50 \% \mathrm{IA} / \mathrm{g}$. A higher value indicated that the animal responded to the therapy, whereas a lower value indicated a non-responder.

\section{Conclusion}

In summary, we have developed an antibody-based companion diagnostic measuring FR $\alpha$ expression in ovarian cancer during ADC therapy. $\left[{ }^{89} \mathrm{Zr}\right] \mathrm{Zr}$-DFO-M9346A was found to be straightforward to radiolabel with $\mathrm{Zr}-89$ after conjugation of desferrioxamine to the antibody. Our PET imaging agent showed excellent in vivo performance delineating $F R \alpha$-positive tumors with high tumor-to-background ratios. Successful in vivo correlation of the pharmacokinetics between companion diagnostic and the radiolabeled ADC allowed us to perform therapy studies allowing the precision prediction of responders and non-responders in small animal studies. In humans, ADC sensitivity likely depends on FR $\alpha$ expression. Intuitively, one of the next steps should be to use this imaging technology in more advanced and heterogeneous mouse models of ovarian cancer. We are confident that $\left[{ }^{89} \mathrm{Zr}\right] \mathrm{Zr}$-DFO-M9346A could ultimately be a suitable companion diagnostic for IMGN853 cancer therapy, quantitatively assessing the folate receptor expression levels non-invasively in patients.

\section{Additional file}

Additional file 1: Figure S1. Size exclusion chromatograms of (a) M9346A and (b) DFO-M9346A. (PDF 279 kb)

Additional file 2: Figure S2. Lindmo immunoreactivity assay for ${ }^{89} \mathrm{Zr}$ labeled DFO-M9346A. (PDF 280 kb)

Additional file 3: Figure S3. Stability study in human plasma of $\left[{ }^{89} \mathrm{Zr}\right] \mathrm{Zr}$-DFO-M9346A. (PDF $280 \mathrm{~kb}$ )

Additional file 4: Figure S4. Serial PET imaging at 4 h, 24 h, 48 h, and $72 \mathrm{~h}$ post-administration of $\left[{ }^{89} \mathrm{Zr}\right] \mathrm{Zr}$-DFO-M9346A in KB tumor bearing mice. (PDF $335 \mathrm{~kb}$ )

Additional file 5: Figure S5. Ex vivo biodistribution study at $24 \mathrm{~h}$ and $72 \mathrm{~h}$ post-injection of [ $\left.{ }^{89} \mathrm{Zr}\right] \mathrm{Zr}$-DFO-M9346A in KB tumor bearing mice. (PDF $335 \mathrm{~kb}$ )

Additional file 6: Figure S6. Ex vivo biodistribution study at $24 \mathrm{~h}$ and $48 \mathrm{~h}$ post-injection of $\left.{ }^{89} \mathrm{Zr}\right] \mathrm{Zr}$-DFO-M9346A in OV90 tumor bearing mice. (PDF $335 \mathrm{~kb}$ )

Additional file 7: Figure S7. Side-by-side comparison of the ex vivo biodistribution at $48 \mathrm{~h}$ post-injection of $\left.{ }^{89} \mathrm{Zr}\right] \mathrm{Zr}$-DFO-M9346A and $\left[{ }^{131} \mathrm{l}\right]$ IMGN853 in OV90 tumor bearing mice. (PDF $102 \mathrm{~kb}$ )

Additional file 8: Figure S8. Weights of individual mouse over time during treatment. (PDF $280 \mathrm{~kb}$ )

\section{Abbreviations}

ADC: Antibody-drug conjugate; CT: Computed tomography; DFO: Deferoxamine; FRa: Folate receptor alpha; HPLC: High-performance liquid chromatography; mAb: Humanized monoclonal antibody; MSKCC: Memorial Sloan Kettering Cancer Center; PBS: Phosphate buffered saline; PET: Positron emission tomography

\section{Acknowledgements}

We thank the staff members of the Small Animal Imaging Core Facility as well as the Radiochemistry and Molecular Imaging Probe Core Facility at Memorial Sloan Kettering Cancer Center. The authors especially thank Brian Zeglis for helpful discussions.

\section{Funding}

This work was supported by National Institutes of Health $(\mathrm{NIH})$ grants R01 CA204441 (T.R.) and P30 CA008748. The authors further thank ImmunoGen, Inc. for generous support.

\section{Availability of data and materials}

Please contact the author for data requests.

\section{Authors' contributions}

$C B, J H, J F P, J L, N V K P, J A K$, and TR designed the experiments. $C B, J H, K G$, and AS conducted the experiments. $C B$ and TR analyzed the data. $C B$ and TR wrote the paper. All authors read and approved the final manuscript.

\section{Ethics approval}

All in vivo studies and procedures were performed in accordance with an approved protocol from the Institutional Animal Care and Use Committee at Memorial Sloan Kettering Cancer Center (MSK). 


\section{Consent for publication}

Not applicable.

\section{Competing interests}

Jose F. Ponte is an employee of ImmunoGen, Inc. The authors declare that they have no competing interests.

\section{Publisher's Note}

Springer Nature remains neutral with regard to jurisdictional claims in published maps and institutional affiliations.

\section{Author details}

'Department of Radiology, Memorial Sloan Kettering Cancer Center, 1275 York Avenue, New York, NY 10065, USA. ${ }^{2}$ Department of Chemistry, Hunter College and PhD Program in Chemistry, The Graduate Center of the City University of New York, New York, NY, USA. ${ }^{3}$ ImmunoGen, Inc, Waltham, MA, USA. ${ }^{4}$ Molecular Pharmacology Program, Memorial Sloan Kettering Cancer Center, New York, NY, USA. ${ }^{5}$ Department of Radiology, Weill Cornell Medical College, New York, NY 620, USA. ${ }^{6}$ Department of Medicine, Memorial Sloan Kettering Cancer Center, New York, NY, USA.

Received: 9 May 2018 Accepted: 7 August 2018

Published online: 28 August 2018

\section{References}

1. Beck A, Goetsch L, Dumontet C, et al. Strategies and challenges for the next generation of antibody-drug conjugates. Nat Rev Drug Discov. 2017;16:315-37.

2. Scott AM, Wolchok JD, Old LJ. Antibody therapy of cancer. Nat Rev Cancer. 2012;12:278-87.

3. Eagan RT, Ingle JN, Rubin J, et al. Early clinical study of an intermittent schedule for maytansine (NSC-153858): brief communication. J Natl Cancer Inst. 1978;60:93-6.

4. Kelemen LE. The role of folate receptor alpha in cancer development, progression and treatment: cause, consequence or innocent bystander. Int J Cancer. 2006:119:243-50

5. Ab O, Whiteman KR, Bartle LM, et al. IMGN853, a folate receptor-a (FRa)targeting antibody-drug conjugate, exhibits potent targeted antitumor activity against FRa-expressing tumors. Mol Cancer Ther. 2015;14:1605-13.

6. Moore KN, Borghaei H, O'Malley DM, et al. Phase 1 dose-escalation study of mirvetuximab soravtansine (IMGN853), a folate receptor atargeting antibody-drug conjugate, in patients with solid tumors. Cancer. 2017:123:3080-7.

7. Moore KN, Martin LP, O'Malley DM, et al. Safety and activity of mirvetuximab soravtansine (IMGN853), a folate receptor alpha-targeting antibody-drug conjugate, in platinum-resistant ovarian, fallopian tube, or primary peritoneal cancer: a phase I expansion study. J Clin Oncol. 2017:35:1112-8.

8. Luyckx M, Votino R, Squifflet JL, et al. Profile of vintafolide (EC145) and its use in the treatment of platinum-resistant ovarian cancer. Int J Womens Health. 2014;6:351-8.

9. Vergote I, Armstrong D, Scambia G, et al. A randomized, double-blind, placebo-controlled, phase III study to assess efficacy and safety of weekly farletuzumab in combination with carboplatin and Taxane in patients with ovarian cancer in first platinum-sensitive relapse. J Clin Oncol. 2016;34:2271-8.

10. Elnakat $H$, Ratnam M. Distribution, functionality and gene regulation of folate receptor isoforms: implications in targeted therapy. Adv Drug Deliv Rev. 2004;56:1067-84.

11. Salazar MD, Ratnam M. The folate receptor: what does it promise in tissuetargeted therapeutics. Cancer Metastasis Rev. 2007;26:141-52.

12. Assaraf $Y G$, Leamon $C P$, Reddy JA. The folate receptor as a rational therapeutic target for personalized cancer treatment. Drug Resist Updat. 2014;17:89-95

13. Ledermann JA, Canevari S, Thigpen T. Targeting the folate receptor: diagnostic and therapeutic approaches to personalize cancer treatments. Ann Oncol. 2015;26:2034-43.

14. Van Heertum RL, Scarimbolo R, Ford R, et al. Companion diagnostics and molecular imaging-enhanced approaches for oncology clinical trials. Drug Des Devel Ther. 2015;9:5215-23.

15. Puranik AD, Kulkarni HR, Baum RP. Companion diagnostics and molecular imaging. Cancer J. 2015;21:213-7.
16. Olsen D, Jørgensen JT. Companion diagnostics for targeted cancer drugs clinical and regulatory aspects. Front Oncol. 2014:4:105.

17. Holland JP, Divilov V, Bander NH, et al. 89Zr-DFO-J591 for immunoPET of prostate-specific membrane antigen expression in vivo. J Nucl Med. 2010;51 1293-300.

18. Viola-Villegas NT, Rice SL, Carlin S, et al. Applying PET to broaden the diagnostic utility of the clinically validated CA19.9 serum biomarker for oncology. J Nucl Med. 2013;54:1876-82.

19. Lindmo T, Boven $E$, Cuttitta F, et al. Determination of the immunoreactive fraction of radiolabeled monoclonal antibodies by linear extrapolation to binding at infinite antigen excess. J Immunol Methods. 1984;72:77-89.

20. Brand C, Longo VA, Groaning M, et al. Development of a new folate-derived Ga-68-based PET imaging agent. Mol Imaging Biol. 2017;19:754-61.

21. Vosjan MJ, Perk LR, Visser GW, et al. Conjugation and radiolabeling of monoclonal antibodies with zirconium-89 for PET imaging using the bifunctional chelate p-isothiocyanatobenzyl-desferrioxamine. Nat Protoc. 2010;5:739-43.

22. Mankoff DA, Edmonds CE, Farwell MD, et al. Development of companion diagnostics. Semin Nucl Med. 2016;46:47-56.

23. Morris RT, Joyrich RN, Naumann RW, et al. Phase II study of treatment of advanced ovarian cancer with folate-receptor-targeted therapeutic (vintafolide) and companion SPECT-based imaging agent (99mTcetarfolatide). Ann Oncol. 2014;25:852-8.

24. Sharma R, Wang WM, Evans J, et al. 68Ga-DOTATATE PET/CT to predict response to peptide receptor radionuclide therapy (PRRT) in neuroendocrine tumours (NETs). J Clin Oncol. 2017:35:4093.

25. Sadowski SM, Neychev V, Millo C, et al. Prospective study of 68Ga-DOTATA TE positron emission tomography/computed tomography for detecting gastro-entero-pancreatic neuroendocrine tumors and unknown primary sites. J Clin Oncol. 2016;34:588-96.

26. Mojtahedi A, Thamake S, Tworowska I, et al. The value of (68) Ga-DOTATATE $\mathrm{PET} / \mathrm{CT}$ in diagnosis and management of neuroendocrine tumors compared to current FDA approved imaging modalities: a review of literature. Am J Nucl Med Mol Imaging. 2014;4:426-34.

27. Forster MD, Ormerod MG, Agarwal R, et al. Flow cytometric method for determining folate receptor expression on ovarian carcinoma cells. Cytometry A. 2007;71:945-50.

28. Pérez-Medina C, Abdel-Atti D, Tang J, et al. Nanoreporter PET predicts the efficacy of anti-cancer nanotherapy. Nat Commun. 2016;7:11838-46.

29. Miller MA, Arlauckas S, Weissleder R. Prediction of anti-cancer nanotherapy efficacy by imaging. Nano. 2017;1:296-312.

\section{Submit your manuscript to a SpringerOpen ${ }^{\circ}$ journal and benefit from:}

- Convenient online submission

- Rigorous peer review

- Open access: articles freely available online

High visibility within the field

- Retaining the copyright to your article

Submit your next manuscript at $\boldsymbol{\nabla}$ springeropen.com 